\title{
Analysis of delivery pattern and neonatal outcome in the calendar year 2015 in urban field practice area of Kamineni Institute of Medical Sciences, Narketpally, India
}

\author{
Sarala K. Balmur'1, Visweswara R. Guthi' ${ }^{2 *}$, Navya K. Naidu²
}

\begin{abstract}
${ }^{1}$ Department of Obstetrics and Gynecology, Kamineni Institute of Medical Sciences, Narketpally, Telangana, India ${ }^{2}$ Department of Community Medicine, Kamineni Institute of Medical Sciences, Narketpally, Telangana, India
\end{abstract}

Received: 30 November 2016

Accepted: 26 December 2016

*Correspondence:

Dr. Visweswara R. Guthi,

E-mail: vissumbbs@gmail.com

Copyright: () the author(s), publisher and licensee Medip Academy. This is an open-access article distributed under the terms of the Creative Commons Attribution Non-Commercial License, which permits unrestricted non-commercial use, distribution, and reproduction in any medium, provided the original work is properly cited.

\begin{abstract}
Background: Neonatal mortality is the number of neonatal deaths in a given year per 1000 live births in that year. It is estimated that 5.9 million children under 5 years of age died in 2015, with a global under-five mortality rate of 42.5 per 1000 live births. Of those deaths, 45\% were newborns, with a neonatal mortality rate of 19 per 1000 live births. The present study aimed at to assess the neonatal mortality in the study area and to study the socio demographic factors, obstetric and neonatal factors among study population.

Methods: This is a Cross-sectional study conducted in the field practice area of Urban Health Centre (UHC) under department of Community Medicine, KIMS, Narketpally, Nalgonda district, Telangana from February 2016 to April 2016. A total of 240 women were included in the study. Information collected was their socio-demographic data, previous and present obstetric history and utilization of health facilities and condition of Baby after birth.

Results: Neonatal mortality rate in the study area during the study period is 8.39/1000 live births. Out of 242 new born babies $129(53.3 \%)$ were males and $113(46.7 \%)$ were females. Majority $(94.2 \%)$ had a birth weight of more than $2.5 \mathrm{kgs}$. Out of 242 babies 7 babies were suffering from congenital anomalies (2), Sepsis (2) and skin infections (3).

Conclusions: Most of the study population were in the age group of 19-25 years, literates, laborers by occupation, Hindu by religion, belong to nuclear families and belong to below poverty line. Most of the new born babies have birth weight $>2.5 \mathrm{kgs}$.
\end{abstract}

Key words: Delivery Pattern, Neonates, Obstetric factors, Socio demographic factors

\section{INTRODUCTION}

Neonatal mortality is the number of neonatal deaths in a given year per 1000 live births in that year. Infant mortality is the most sensitive index to measure socioeconomic development and the quality of life. ${ }^{1}$

It is estimated that 5.9 million children under 5 years of age died in 2015 , with a global under-five mortality rate of 42.5 per 1000 live births. Of those deaths, $45 \%$ were newborns, with a neonatal mortality rate of 19 per 1000 live births. ${ }^{1,2}$ Multiple factors such as socio-economic conditions, environment and health care has significant effect on childhood mortality and improving child survival is a national Priority in health care. The World Health Organization is working with governments worldwide to improve neonatal and child survival. ${ }^{1}$ More recently with the introduction of Sustainable Development Goals (SDGs) the target (3.2.2) for Neonatal mortality was set as low as 12 per 1000 live births which should be attained by 2030 .

Therefore the authors decided to carry out a study to find the specific neonatal mortality rate and its associated 
obstetrics and morbidity factors in an urban slum area. The objectives of this study are to assess Neonatal Mortality Rate in the study area and to study socio demographic factors, obstetric and neonatal factors among the study population.

\section{METHODS}

This is a Cross-sectional study conducted in the field practice area of Urban Health Centre (UHC), under department of Community Medicine, Kamineni Institute of Medical Sciences, Narketpally, Nalgonda district, Telangana. This study was conducted during February 2016 to April 2016.

Married women in the reproductive age group, who delivered in the calendar year of 2015 ( $1^{\text {st }}$ January 2015 to $31^{\text {st }}$ December 2015) and willing to participate were included in the study.

A total of 240 women were delivered in the study area during calendar year $1^{\text {st }}$ January 2015 to $31^{\text {st }}$ December 2015 according MPHW(F) ANC register of UHC were included in the study.

A predesigned structured questionnaire was used for the face to face interview. House to house visits were made to each subject and face to face interview was conducted after obtaining consent, and information collected was their socio-demographic data, previous and present obstetric history and utilization of health facilities and condition of Baby after birth. The data collected was analyzed using SPSS version 21.

\section{RESULTS}

Table 1 shows that the study sample contained 240 women. Among the study subjects 199 (82.9\%) of the mothers were in the age group of 19-25 years and 41 $(17.1 \%)$ were in the age group of 26-35 years. Majority $157(65.4 \%)$ of the study subjects were literates but predominantly were daily wagers $202(84.2 \%)$.

Religion wise Hindus were more in number $182(75.8 \%)$ followed by Muslims 38(15.8\%) and Christians 20 (8.4\%). Caste wise $179(74.6 \%)$ belong to other castes followed by SC $57(23.7 \%)$ and ST 4 (1.7\%). Type of family wise $134(55.8 \%)$ study subjects belong to nuclear family followed by 106 (44.2\%) subjects belong to joint family. Majority of the study population fall below poverty line category $(84.2 \%)$.

Table 2 shows that among the 240 women who had participated in the study, majority of them $197(82.1 \%)$ had married at the age of 19-25 years. $28(11.7 \%)$ of the study subjects had consanguineous marriage.

Among the study subjects multiparous women were more $137(57 \%)$ as compared to primiparous women 103 (43\%). Among the multiparous women 124 (51.7\%) individuals followed spacing between pregnancies for more than 2 years and $13(5.4 \%)$ women followed spacing for less than 2 years.

Among 240 women who delivered in the calendar year of 2015, 108 (45\%) women delivered at Government facility and $132(55 \%)$ women delivered at private facility.

Only 50 (20.8\%) individuals had normal vaginal delivery and rest of them 190 (79.2\%) had Lower segment caesarean section. Majority of the study subjects 231 $(96.3 \%)$ were delivered at full term, only $9(3.7 \%)$ delivered at preterm.

\section{Table 1: Socio-demographic data of the study population.}

\begin{tabular}{|c|c|c|}
\hline $\begin{array}{l}\text { Socio } \\
\text { demographic } \\
\text { factors of } \\
\text { mothers }\end{array}$ & $\begin{array}{l}\text { Number } \\
(n=240)\end{array}$ & $\begin{array}{l}\text { Percentage } \\
(\%)\end{array}$ \\
\hline \multicolumn{3}{|c|}{ Age group (years) } \\
\hline $19-25$ & 199 & 82.9 \\
\hline $26-35$ & 41 & 17.1 \\
\hline \multicolumn{3}{|c|}{ Education of the mother } \\
\hline Literate & 157 & 65.4 \\
\hline Illiterate & 83 & 34.6 \\
\hline \multicolumn{3}{|l|}{ Occupation } \\
\hline Labour & 202 & 84.2 \\
\hline Service & 38 & 15.8 \\
\hline \multicolumn{3}{|l|}{ Religion } \\
\hline Hindu & 182 & 75.8 \\
\hline Muslim & 38 & 15.8 \\
\hline Christian & 20 & 8.4 \\
\hline \multicolumn{3}{|l|}{ Caste } \\
\hline $\mathrm{SC}$ & 57 & 23.7 \\
\hline ST & 4 & 1.7 \\
\hline Others & 179 & 74.6 \\
\hline \multicolumn{3}{|l|}{ Type of family } \\
\hline Nuclear & 134 & 55.8 \\
\hline Joint & 106 & 44.2 \\
\hline \multicolumn{3}{|c|}{ Socio-economic status } \\
\hline $\begin{array}{l}\text { Above Poverty } \\
\text { Line }\end{array}$ & 38 & 15.8 \\
\hline $\begin{array}{l}\text { Below Poverty } \\
\text { Line }\end{array}$ & 202 & 84.2 \\
\hline Total & 240 & 100 \\
\hline
\end{tabular}

There were 2 Neonatal deaths among 239 study population. So, Neonatal mortality rate in the study area during the study period is $8.39 / 1000$ live births.

Table 3 shows that out of 242 new born babies $129(53.3 \%)$ were males and $113(46.7 \%)$ were females. Majority $(94.2 \%)$ had a birth weight of more than 2.5 kgs. Out of 242 babies 7 babies were suffering from congenital anomalies (2), Sepsis (2) and skin infections (3). 
Table 2: Obstetric factors of the study population.

\begin{tabular}{|c|c|c|}
\hline $\begin{array}{l}\text { Obstetric } \\
\text { factors }\end{array}$ & $\begin{array}{l}\text { Number } \\
(n=240)\end{array}$ & $\begin{array}{l}\text { Percentage } \\
(\%)\end{array}$ \\
\hline \multicolumn{3}{|c|}{ Age at marriage (Years) } \\
\hline$<18$ & 33 & 13.7 \\
\hline $19-25$ & 197 & 82.1 \\
\hline $26-35$ & 10 & 4.2 \\
\hline \multicolumn{3}{|c|}{ Consanguinity } \\
\hline Yes & 28 & 11.7 \\
\hline No & 212 & 88.3 \\
\hline \multicolumn{3}{|l|}{ Parity } \\
\hline Primi & 103 & 43.0 \\
\hline Multi & 137 & 57.0 \\
\hline \multicolumn{3}{|l|}{ Spacing } \\
\hline$<2$ years & 13 & 5.4 \\
\hline$>2$ years & 124 & 51.7 \\
\hline Primi & 103 & 43.0 \\
\hline \multicolumn{3}{|c|}{ Place of delivery } \\
\hline Government & 108 & 45.0 \\
\hline Private & 132 & 55.0 \\
\hline \multicolumn{3}{|c|}{ Type of delivery } \\
\hline Normal & 50 & 20.8 \\
\hline $\begin{array}{l}\text { Lower Segme } \\
\text { Caesarean } \\
\text { Section }\end{array}$ & 190 & 79.2 \\
\hline \multicolumn{3}{|c|}{ Gestational age } \\
\hline Pre term & 9 & 3.7 \\
\hline Full term & 231 & 96.3 \\
\hline Total & 240 & 100.0 \\
\hline
\end{tabular}

Table 3: Neonatal factors of the study population.

\begin{tabular}{|c|c|c|}
\hline $\begin{array}{l}\text { Neonatal } \\
\text { factors }\end{array}$ & $\begin{array}{l}\text { Number } \\
(\mathrm{n}=\mathbf{2 4 2}) *\end{array}$ & $\begin{array}{l}\text { Percentage } \\
(\%)\end{array}$ \\
\hline \multicolumn{3}{|l|}{ Sex of the baby } \\
\hline Male child & 129 & 53.3 \\
\hline Female child & 113 & 46.7 \\
\hline \multicolumn{3}{|c|}{ Weight of the baby } \\
\hline$<2.5 \mathrm{kgs}$ & 14 & 5.8 \\
\hline$>2.5 \mathrm{kgs}$ & 228 & 94.2 \\
\hline Total & 242 & 100.0 \\
\hline \multicolumn{3}{|c|}{ Morbidity factors } \\
\hline $\begin{array}{l}\text { Congenital } \\
\text { anomalies }\end{array}$ & 2 & 28.6 \\
\hline Sepsis & 2 & 28.6 \\
\hline Skin infections & 3 & 42.8 \\
\hline Total & 7 & 100 \\
\hline
\end{tabular}

$*_{n}=242$ as there was two twin pregnancies

\section{DISCUSSION}

This is a Cross-sectional study conducted in the urban field practice area of Kamineni Institute of Medical Sciences, Narketpally, Nalgonda district, Telangana. Neonatal mortality rate in the study area during the study period was 8.39/1000 live births. Out of 242 new born babies $129(53.3 \%)$ were males and $113(46.7 \%)$ were females. Majority (94.2\%) had a birth weight of more than $2.5 \mathrm{kgs}$. Out of 242 babies 7 babies were suffering from congenital anomalies (2), Sepsis (2) and skin infections (3).

A study conducted by Yashpal Jain revealed that Sepsis was the most important cause of death particularly in the late neonatal period. Birth asphyxia, pneumonia and RDS were the other important causes of death contributing predominantly to the early neonatal deaths. In $13 \%(9 / 69)$ cases no definite conclusion can be drawn about cause of death. ${ }^{4}$ Bang et al found neonatal sepsis $(52 \%)$ as the major cause of death followed by birth asphyxia (20\%) and prematurity $(15 \%)$. In this study pneumonia was included as a septic cause of death. Bang7 also observed that all deaths due to prematurity and asphyxia occurred in first 3 days of life, while all sepsis deaths took place after 3rd day of life. ${ }^{5}$ WHO observed that the direct causes of neonatal deaths globally are infection (32\%), asphyxia (29\%), prematurity $(24.5 \%)$, congenital malformation $(10 \%)$, and others $(5 \%) .{ }^{6}$ National neonatal and perinatal data base (NNPD) in its hospital based study observed that neonatal sepsis accounts for $23 \%$ neonatal deaths in hospital born children and 36\% deaths in out born children. Other causes of death were Birth asphyxia (20\%) abnormal jaundice (1.7\%), and congenital malformation $(2 \%){ }^{7}$

In a study conducted in and around Patna on 1000 neonatal deaths prematurity including low birth weight was the most important cause of neonatal deaths (25.4\%;). Other important causes of neonatal deaths were birth injury/asphyxia and neonatal sepsis. Deaths due to prematurity, congenital malformation, respiratory distress syndrome, neonatal pneumonia, post natal aspiration were more common during first seven days of life. Deaths due to birth injury/asphyxia, neonatal sepsis, neonatal tetanus and sudden deaths were more common during 8-28 days of life. ${ }^{8}$

\section{CONCLUSION}

Most of the study population were in the age group of 1925 years, literates, laborers by occupation, Hindu by religion, belong to nuclear families and belong to below poverty line. Most of the study population married at 1925 years, primi, delivered by caesarian section and full term pregnancies. Most of the new born babies have birth weight $>2.5 \mathrm{KGs}$.

\section{Funding: No funding sources Conflict of interest: None declared \\ Ethical approval: The study was approved by the Institutional Ethics Committee}

\section{REFERENCES}

1. Vaid A, Mammen A. Infant Mortality in an Urban Slum. Indian J Pediatr. 2007;74(5):449-53. 
2. World health statistics. Monitoring of health for SDGs WHO publication. 2016.

3. Nair M. Impact of nonhealth policies on infant mortality through the social determinants pathway, Bulletin of the World Health Organization. 2011;89:778-8.

4. Jain Y, Bansal M. Causes of neonatal mortality: a community based study using verbal autopsy tool. National Journal of Community Medicine. 2013;4(3):498-502.

5. Bang A, Reddy MH, Deshmukh MD. Child mortality inMahararshtra. Economic Political Weekly. 2002;37:4947-65.

6. World health report,2006, working together for health, 2006

7. Investigators of National Neonatal Perinatal Database. Morbidity and mortality among outborn neonates at 10 tertiary care institutions in India during year 2000. J Trop Pediatr Res. 2004;50:170-4.

8. Shrivastava SP, Anjani K. From the Upgraded Department of Pediatrics, Patna Medical College and Hospital, Patna 800 004, India Manuscript received: March 11, 1998; Initial review completed: April 23, 1998; Revision accepted: February 22, 2001.

Cite this article as: Sarla $\mathrm{KB}$, Viswesvara $\mathrm{RG}$, Navya KN. Analysis of delivery pattern and neonatal outcome in the calendar year 2015 in urban field practice area of Kamineni Institute of Medical Sciences, Narketpally, India. Int J Reprod Contracept Obstet Gynecol 2017;6:591-4. 